\title{
PERANCANGAN MESIN PERONTOK PADI DENGAN SUMBER ENERGI SURYA
}

\author{
Abdul Tahir ${ }^{1, ~ a ~}{ }^{*}$, Harman ${ }^{2, b}$ \\ ${ }^{1}$ Akademi Teknik Soroako , \\ aabdultahir@ats-sorowako.ac.id, bharman@ats-sorowako.ac.id
}

\begin{abstract}
Abstrak
Proses perontokan padi dengan menggunakan power thresher dapat meningkatkan hasil produktivitas padi hingga $500-600 \mathrm{Kg} / \mathrm{jam}$. Penelitian ini bertujuan untuk merancang mesin perontok padi yang menggunakan sumber energi surya sebagai energi penggerak motor. Metode penelitian yang digunakan adalah metode experimental yang terdiri dari beberapa tahap yang garis besarnya dimulai dari merencana, mengkonsep, merancang, dan finalisasi. Dalam membuat konstruksi mesin maka terlebih dahulu dilakukan perancangan dan perhitungan kekuatan bahan dan elemen mesin yang digunakan serta juga perancangan perawatan dan perakitan dengan tujuan untuk mengetahui sumber dan kapasitas motor penggerak yang dibutuhkan serta dimensi-dimensi komponen yang digunakan. Berdasarkan hasil perhitungan daya motor yang sesuai untuk digunakan yaitu motor AC dengan daya 1,5 HP. Panel surya yang diperlukan adalah yang dapat menghasilkan energi 300 wp menggunakan aki kering dengan spesifikasi 12 Volt/100Ah. Untuk mengubah arus searah (DC) menjadi arus bolak-balik (AC) digunakan sebuah inverter dan solar charger controler 10A untuk mengontrol pengisian baterai. Hasil dari perancangan ini didapatkan model mesin perontok padi yang siap untuk diproduksi.
\end{abstract}

Kata kunci : Padi, perontok, motor listrik, energi surya, kapasitas, panel surya

\begin{abstract}
The process of threshing rice using a power thresher can increase the yield of rice productivity up to 500-600 Kg/hour. This study aims to design a rice threshing machine that uses solar energy as a motor driving energy. The research method used is an experimental method which consists of several stages whose outline starts from planning, conceptualizing, designing, and finalizing. In making the construction of the machine, first, the design and calculation of the strength of the materials and machine elements used as well as the design of maintenance and assembly is carried out with the aim of knowing the source and capacity of the driving motor needed and the dimensions of the components used. Based on the results of the calculation of the appropriate motor power to be used, namely an AC motor with a power of $1.5 \mathrm{HP}$. The solar panels needed are those that can produce $300 \mathrm{wp}$ of energy using a dry battery with a specification of 12 Volt/100Ah. To convert direct current (DC) into alternating current (AC), an inverter and a $10 \mathrm{~A}$ solar charger controller are used to control battery charging. The results of this design obtained a model of a rice thresher machine that is ready to be produced.
\end{abstract}

Keywords: Rice, thresher, electric motor, solar energy, capacity, solar panels

\section{PENDAHULUAN}

Pascapanen merupakan tindakan yang disiapkan atau dilakukan untuk menekan kehilangan hasil panen pada saat perlakuan setelah panen sampai siap dipasarkan. Kegiatan pascapanen akan memberikan hasil yang memuaskan apabila dilakukan pada waktu yang tepat dan penggunaan alat yang tepat juga [1]. 
Telah banyak inovasi dari peneliti untuk petani yang telah dilakukan dalam upaya mengembangkan metode perontokan padi, diantaranya menggunakan Pedal Thresher dimana sistim penggeraknya manual dengan menggunakan gerakan kaki. Produktivitas dari metode ini dianggap masih relatif rendah .Hasil produktivitas gabah dengan metode ini hanya mencapai 86,4 $\mathrm{Kg} / \mathrm{jam}$ [2]. Inovasi lain adalah menggunakan Metode power thresher yang dapat memproduksi gabah lebih cepat dan gabah dihasilkan cukup bersih. Power thresher menggunakan tenaga penggerak motor berbasis diesel dan bensin dengan kapasitas 5,5-6 HP dengan produktifitas 500 hingga $600 \mathrm{~kg}$ gabah per jam. Penggunaan Power thresher memberikan manfaat karena selain meningkatkan produktifitas juga mempermudah proses perbaikan dan perawatannya, serta mudah diproduksi [3]. Dalam penggunaan Power thresher beberapa hal yang perlu diperhatikan sebab memerlukan ketrampilan dalam pengoperasiannya. Mesin Power Tresher dengan bobot yang berat masih beresiko tenggelam jika dioperasikan dilahan pertanian yang basah dan berlumpur, disamping itu harganya masih terbilang mahal bagi individu petani. Mesin ini menggunakan bahan bakar fosil yang dapat menambah pengeluaran petani, penggunaan bahan bakar fosil sebagai energi penggerak juga mengakibatkan pencemaran udara. Saat ini alternatif energi yang dapat digunakan sebagai pengganti bahan bakar adalah menggunakan energi dari panas matahari. Provinsi Sulawesi Selatan memiliki potensi yang besar untuk pemanfaatan energi matahari, hal ini didukung dengan ketersediaan radiasi matahari yang cukup besar sepanjang tahun yaitu sebesar $929,10251 \mathrm{~W} / \mathrm{m}^{2}$. Berdasarkan peta insolasi matahari dunia, daerah sulawesi memiliki jam Matahari Ekivalen atau Equivalent Sun Hours (ESH) sebesar 4,5 kWh/m2/hari
[4]. Pemanfaatan energi surya sebagai sumber energi penggerak mesin-mesin pertanian merupakan suatu hal yang masih baru dalam dunia pertanian Indonesia khususnya di Kawasan Timur Indonesia sehingga perlu dilakukan kajian dan penelitian yang komprehensif tentang pemamfaatan energi matahari tersebut untuk meningkatkan produktifitas hasil hasil pertanian para petani. Salah satu pemamfaatn energi matahari yang sangat penting dalam bidang pertanian adalah Penggunaan Energi Matahari untuk menggerakan mesin-mesin pertanian seperti mesin perontok padi. Penelitian ini bertujuan untuk memrancang mesin perontok padi dengan penggerak motor $\mathrm{AC}$ menggunakan energi matahari.

\section{METODE PENELITIAN}

Metode penelitian yang digunakan adalah metode experimental untuk perancangan yang dimulai dengan identifikasi masalah yang terjadi dilapangan melalui observasi langsung juga study literatur. Perancangan dilanjutkan dengan membuat daftar tuntutan, pembagian fungsi bagian, alternatif fungsi bagian, dan penilaian alternatif. Hasil penilaian alternatif adalah konsep rancangan sebagai pemecahan dari masalah yang terjadi. Setelah konsep rancangan didapatkan maka dilanjutkan dengan pembuatan rancangan. Adapun diagram proses tahap-tahap perancangan dapat dilihat pada gambar 1 . 


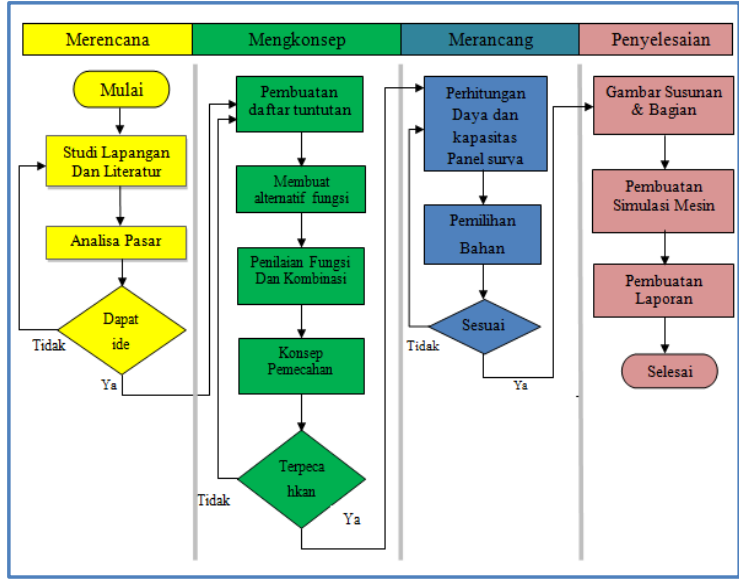

Gambar 1 tahap - tahap perancangan mesin perontok padi

\section{Daftar Tuntutan}

Dalam proses perancangan dilakukan penetapan daftar tuntutan yang harus dipenuhi agar mesin yang dirancang dapat berfungsi dengan maksimal [5], daftar tuntutan ini juga digunakan sebagai dasar pemberian bobot nilai untuk setiap alternatif fungsi bagian. Berikut merupakan daftar tuntutan yang ditentukan untuk perancangan.

1) Ringan, artinya mesin dapat dipindahkan tanpa menggunakan alat transportasi seperti mobil dan sejenisnya

2) Material mudah didapatkan, artinya material yang digunakan mudah didapatkan dan tersedia secara local

3) Mudah dikerjakan, artinya mesin/alat yang dirancang mudah dibuat/ tidak sulit untuk dikerjakan

4) Mudah dirakit, artinya hasil rancangan dari bagian-bagian mesin nantinya mudah dirakit atau bongkar pasang

5) Mudah dirawat, artinya mesin yang dirancang memiliki kemudahann dalam perawatan

6) Mudah dioperasikan, artinya mesin yang dirancang mudah dijalankan dan aman dari kemungkinan terjadinya kecelakaan.

\section{Pembagian Fungsi Bagian}

Langkah penguraian dan pembagian fungsi bagian merupakan aktivitas pengumpulan ide untuk mendapatkan solusi terbaik. Berikut merupakan pembagian fungsi dari mesin yang dirancang :

1) Profil Rangka Mesin

Rangka mesin berfungsi untuk menopang silinder perontok, panel serta seluruh komponen mesin perontok padi.

2) Silinder Perontok

Silinder perontok berfungsi untuk merontokkan padi dari tangkaia serta mengarahkan jerami menuju lubang pembuangan jerami.

3) Sistem Penggerak

Sistem penggerak berupa motor yang berfungi menghasilkan putaran

4) Sistem Transmisi

Sistem transmisi berfungsi untuk meneruskan putaran dari motor penggerak ke silinder perontok.

5) Sistem Transportasi

Sistem tranportasi berupa roda berfungsi untuk mempermudah proses mobilitas mesin perontok saat akan dipindahkan.

6) Sistem Pembersih

Sistem pembersih berfungsi untuk memisahkan gabah berisi dengan gabah hampa saat terjadi perontokan pada silinder perontok.

\section{Alternatif Fungsi Bagian}

Pada tahapan ini, uraian pada setiap fungsi bagian diberikan alternatif konsep dengan tujuan mencari fungsi yang paling optimal berdasarkan parameter penilaian yang diberikan, jumlah alternatif yang diberikan untuk setiap fungsi bagian terdiri dari 3 alternatif kombinasi sebagai mana yang diperlihatkan pada tabel 1 .

Dari tiga kombinasi alternatif yang diberikan selanjutnya akan dipilih alternatif yang paling sesuai dengan melakukan pemilihan dengan memperhatikan faktor: harga, berat, ketersediaan, perawatan, dan pengoperasian. 
Tabel 1 Kombinasi Fungsi Bagian

\begin{tabular}{|c|c|c|c|c|}
\hline No & Fungsi Bagian & Alternatif 1 & Alternatif 2 & Alternatif 3 \\
\hline \multirow[t]{2}{*}{1.} & Profili Rangka & & & \\
\hline & & Profil L & Hollow & Profil C \\
\hline & Silinder & & & \\
\hline & & Tabung & Pentagonal & Plat Strip Bar \\
\hline 3 & Sistem & & & \\
\hline & Lesnggeraks & & & \\
\hline & & Motor DC & Motor AC & \\
\hline \multirow{3}{*}{4} & Sistem & & & \\
\hline & Ltansmosst & & & \\
\hline & & Chain Sprocket & Pulley Belt & \begin{tabular}{|l|} 
Timing Belt \\
\end{tabular} \\
\hline \multirow{3}{*}{5} & Sistem & & & \\
\hline & Txanspostasi & & & \\
\hline & & Roda Sepeda & Roda Traktor & Roda Lori \\
\hline \multirow{3}{*}{6} & Sitem & & (3) & \\
\hline & Pembersih & $\sin$ & 1\% & \\
\hline & & Elektrik Fan & Manual Fan & \\
\hline
\end{tabular}

\section{Penilaian Alternatif}

Proses penilaian alternatif rancangan dilakukan dengan cara menghubungkan masing-masing alternatif fungsi bagian komponen satu dengan yang lain atau disebut metode diagram morfologi. Dari hasil penilaian alternatif ini diambil yang paling optimal dan dijadikan sebagai konsep rancangan yang akan dibuat.

\section{Variasi Konsep}

Perlu ditentukan beberapa variasi konsep untuk selanjutnya dipilih menjadi sebuah konsep yang akan di tetpkan sebagai hasil dari rancangan.

\section{Perencanaan Sistem Panel Surya}

Perancangan mesin perontok padi ini menggunakan solar sel dengan beberapa komponen pendukung yang terdiri dari panel solar cell, charger controller, accu, inverter dan montor AC sebagai penggerak. Seluruh komponen dirangkai sehingga dapat menghasilkan listrik yang akan menghidupkan motor penggerak mesin perontok. Gambar 2 merupakan rancangan rangkain komponen sistem pembangkit listrik dengan energi surya yang digunakan sebagai energi penggerak pada mesin perontok padi. Motor penggerak yang digunakan adalah motor AC yang bekerja pada tegangan $220 \mathrm{~V}$. Oleh karena itu untuk mengubah tegangan aki $12 \mathrm{~V}$ diperlukan sebuah inverter.

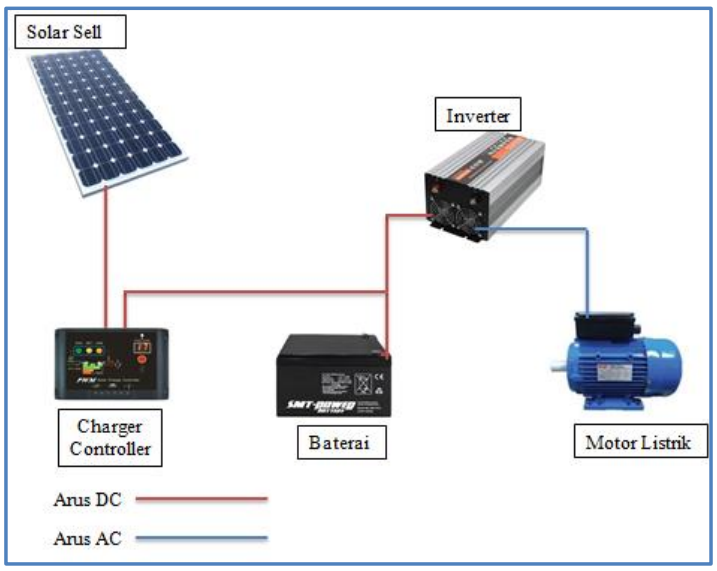

Gambar 2 Rangkaian Komponen Panel Surya

Perencanaan Kapasitas Panel Surya

Total Kebutuhan Daya

$\mathrm{P}_{\text {tot }}=\mathrm{P} \times \mathrm{t}$

Keterangan :

$\mathrm{P}_{\text {tot }}=$ Energi Yang digunakan $(\mathrm{Wh})$

$\mathrm{P}$ = Daya Listrik ( W )

$\mathrm{t}=$ Tot.Wkt penggunaan/hari (hour)

Jumlah Kebutuhan Solar Cell

$P_{\text {solar sel }}=\frac{\text { Tot.Daily Power }\left(\frac{\text { Watt }}{\text { Day }}\right)}{\text { Charging Effective }(\text { hour })}$

Jumlah Panel Surya $=\frac{\mathrm{P}_{\mathrm{wp}}}{\mathrm{P}_{\max }}$

Keterangan :

$\mathrm{P}_{\mathrm{wp}}=$ Tot. kebutuhan s. sell ( Wp )

$\mathrm{P}_{\max }=$ Daya maksimal s. sell/unit ( Wp )

\section{HASIL DAN PEMBAHASAN}

Hasil Pemilihan Alternatif

Berdasarkan penilaian alternatif fungsi didapatkan alternatif terpilih. Alternatif terpilih adalah alaternatif yang memiliki skor tertinggi dengan penilaian didasarkan pada daftar tuntutan dan kriteria penilaian. Berikut adalah tabel daftar alternatif terpilih.

Tabel 2 Alternatif Terpilih 
p-ISSN 2502-4922,e-ISSN 2615-0867

\begin{tabular}{ccc}
\hline No & Komponen & Alternatif \\
\hline 1. & $\begin{array}{c}\text { Profil } \\
\text { Rangka } \\
\text { Mesin }\end{array}$ & $\begin{array}{c}\text { Alternatif 1 } \\
\text { (Profil L) }\end{array}$ \\
\hline 2. & $\begin{array}{c}\text { Silinder } \\
\text { Perontok }\end{array}$ & $\begin{array}{c}\text { Alternatif 3 } \\
\text { (Plat Strip) }\end{array}$ \\
\hline 3. & Sistem & Alternatif 2 \\
Penggerak & (Motor AC) \\
\hline 4. & Sistem & $\begin{array}{c}\text { Alternatif 2 } \\
\text { (Pulley Belt) }\end{array}$ \\
\hline 5. & Transmisi & Sistem \\
& Transportasi & $\begin{array}{c}\text { Alternatif 1 } \\
\text { (Rda Sepeda) }\end{array}$ \\
\hline 6. & Sistem & Alternatif 1 \\
& Pembersih & kipas Elektrik)
\end{tabular}

Setelah mendapatkan alternatif fungsi bagian selanjutnya dilakukan penyusunan konsep bentuk rancangan. Konsep bentuk rancangan seperti pada gambar 3.

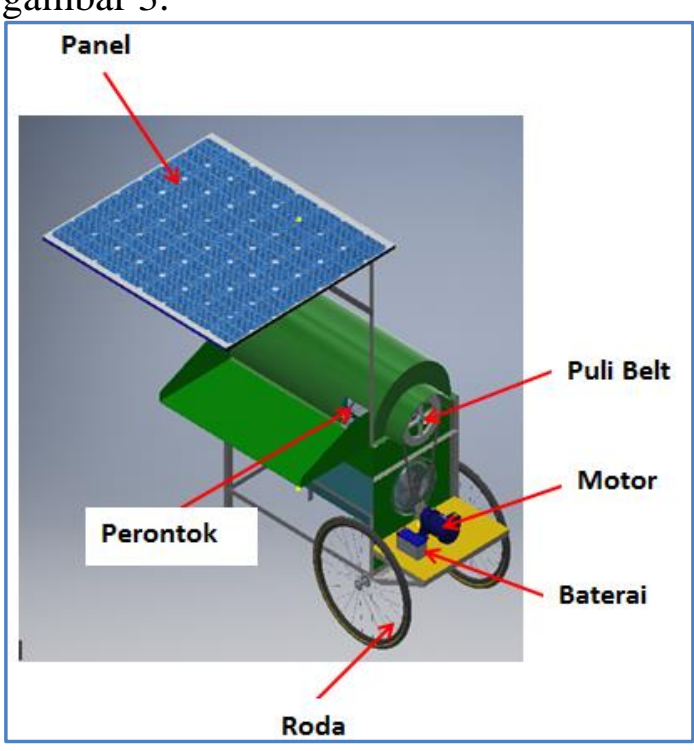

Gambar 3 Konsep Bentuk Rancangan

Setelah didaptkan konsep bentuk rancangan maka selanjutnya dilakukan pembuatan gambar bagian setiap komponen pendukung mesin. Hasil dari gambar susunan dan nama bagian dapat dilihat pada pada tabel 3 dan gambar 4 dan 5 .

Tabel 3 Nama Bagian-Bagian Mesin

\begin{tabular}{cccc}
\hline No & $\begin{array}{c}\text { Nama } \\
\text { Bagian }\end{array}$ & No & $\begin{array}{c}\text { Nama } \\
\text { Bagian }\end{array}$ \\
\hline 1. & Rangka & 12. & Plat Input \\
2. & $\begin{array}{c}\text { Penutup } \\
\text { Silinder }\end{array}$ & 13. & Panel Surya \\
3. & $\begin{array}{c}\text { Pengayak } \\
\text { Silinder }\end{array}$ & 14. & Roda \\
4. & $\begin{array}{c}\text { Perontok } \\
\text { Saluran } \\
\text { Gabah }\end{array}$ & 15. & Kipas \\
5. & $\begin{array}{c}\text { Motor Listrik } \\
\text { Pengarah } \\
\text { Belakang }\end{array}$ & 17. & Pulley 2 \\
7. & $\begin{array}{c}\text { Pengarah } \\
\text { Depan }\end{array}$ & 18. & Belt \\
8. & $\begin{array}{c}\text { Penutup } \\
\text { Belakang } \\
\text { Dudukan }\end{array}$ & 19. & Pillow \\
Kipas & 20. & Plok \\
10. & $\begin{array}{c}\text { Penutup } \\
\text { Samping }\end{array}$ & 21. & Baut \\
11. & $\begin{array}{c}\text { Dudukan } \\
\text { Motor }\end{array}$ & 22. & Mur \\
\hline
\end{tabular}

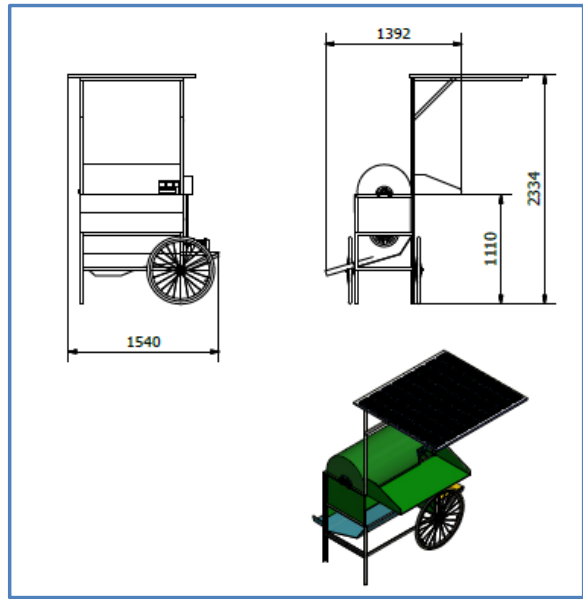

Gambar 4. Gambar Susunan

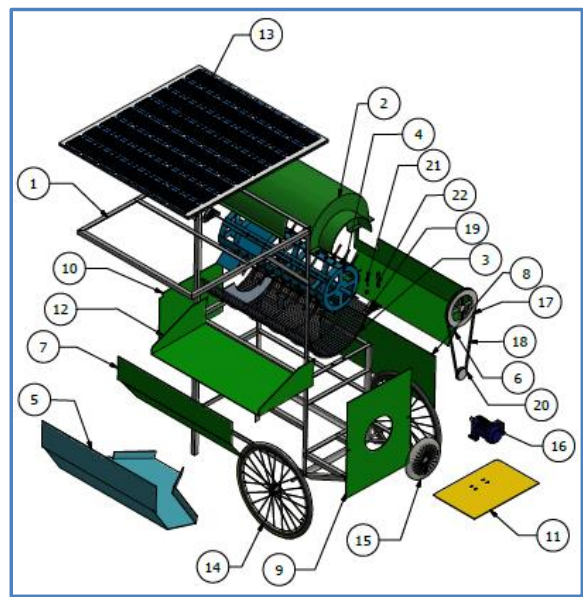

Gambar 4. Gambar Bagian-Bagian Mesin 
p-ISSN 2502-4922,e-ISSN 2615-0867

Untuk memudahkan proses perakitan mesin diberikan petunjuk perakitan dari rancangan yang dibuat, penjelasan perakitan secara berurut sebagai beikut :

1. Merakit profil rangka mesin kemudian las sebagai elemen pengikat.

2. Pasang pengayak di bagian tengah body mesin kemudian perkuat dengan pengelasan.

3. Pasang pillow block bearing dan silinder perontok pada mesin.

4. Kemudian pasang baut atau gigi perontok pada selinder perontok.

5. Kemudian pasang mur pada gigi perontok lalu kencangkan.

6. Pasang plate pengarah belakang pada body mesin.

7. Pasang plate pengarah depan.

8. Kemudian pasang plate penutup belakang.

9. Pasang plate dudukan kipas pada mesin.

10. Kemudian pasang plate penutup samping.

11. Pasang plate saluran keluar gabah

12. Kemudian pasang plate dudukan motor dan batterai.

13. Kemudian pasang kipas pada plate dudukan .

14. Kemudian pasang motor listrik pada plate dudukan motor.

15. Kemudian pasang pulley 2 pada poros selinder perontok.

16. Kemudian pasang belt pada pulley 2 .

17. Kemudian pasang pulley 1 pada motor kemudian hubungkan dengan pulley 2 dengan $\mathrm{v}$ belt.

18. Kemudian pasang roda.

19. Kemudian pasang panel surya.

20. Pasang penutup selinder.

\section{Perhitungan Panel Surya}

Total Kebutuhan Daya didapatkan dari persamaan (1). Motor listrik yang digunakan memikiki daya 1,5 HP atau 1119 Watt, Daya Kipas Elektrik 80 Watt dengan asusmsi pemakaian W 1 Jam, maka didapatkan Total daya yang dibutuhkan seperti tabel berikut .
Tabel 3. 1 Penggunaan Daya

\begin{tabular}{|c|c|c|c|}
\hline Unit & $\begin{array}{c}\text { Daya } \\
\text { (watt) }\end{array}$ & $\begin{array}{l}\text { Jam } \\
\text { Kerja } \\
\text { (Jam) }\end{array}$ & $\begin{array}{l}\text { Ptot }= \\
\mathbf{P} \times h\end{array}$ \\
\hline $\begin{array}{l}\text { Motor } \\
\text { Listrik }\end{array}$ & 1119 & 1 & 1119 \\
\hline Kipas & 80 & 1 & 80 \\
\hline & Total & & 1199 \\
\hline
\end{tabular}

\section{Jumlah kebutuhan solar sel}

Secara umum di Indonesia energi surya yang dapat diserap dan dikonversi menjadi energi listrik berlangsung selama 5 jam. Dengan demikian untuk kebutuhan daya 1199 Wh/Hari dan waktu pengisian Charging Effective 5 Jam, maka Kapasitas Panel Surya (KPS) dapat dihutung dengan persamaan (2)

$$
\begin{aligned}
\text { KPS } & =\frac{\text { Total Daily Watt }\left(\frac{\text { Watt }}{\text { Day }}\right)}{\text { Charging Effective }(\text { hour })} \\
& =\frac{1199}{5} \\
& =\mathbf{2 3 9}, \mathbf{8} \mathbf{w p} \approx \mathbf{3 0 0} \mathbf{w p}
\end{aligned}
$$

\section{KESIMPULAN}

- Perancangan mesin perontok padi yang telah dibuat berukuran $1000 \mathrm{x}$ $600 \times 2300 \mathrm{~mm}$ dengan perencanaan menggunakan material: besi profil L, MS Plate, dan roundbar, serta menggunakan energi matahari sebagai energi penggeraknya.

- Mesin perontok padi yang di rancang memerlukan panel surya berkapasitas 300 wp 1 buah untuk menggerakkan motor AC menggnakan inverter dan dengan dengan kebutuhan daya total 1199 Watt.

\section{REFERENSI}

[1] R. Mislaini, "Rancang Bangun Dan Uji Teknis Alat Perontok Padi," Jurnal Teknologi Pertanian Andalas Vol. 20, pp. ISSN 14101920, 2016. 
[2] A. Kristanto dan S. C. Widodo, "Perancangan Ulang Alat Perontok Padi Yang Ergonomis Untuk Meningkatkan Produktivitas Dan Kualitas Kebersihan Padi," Jurnal Ilmiah Teknik Industri, vol. 14, no. ISSN 1412-6869, pp. 78-85, 2015.

[3] A. Ruswandi, T. Subarna dan S. Bachrein, "Pengkajian Pemanfaatan Mesin Perontok Gabah (Thresher) Dan Mesin Pengering Gabah (Dryer) Padi Sawah Di Jawa Barat," Jurnal Pengkajian dan Pengembangan Teknologi Pertanian, vol. 13, pp. 93-106, 2010.

[4] S. Aryza, Hermansyah dan A. P. U. Siahaan, "Implementasi Energi Surya Sebagai Sumber Suplai Alat Pengering Pupuk Petani Portabel," IT Journal Research and Development, vol. 2, no. e-ISSN: 2528-4053, pp. 12-18, 2017.

[5] Y. Y. Erlanggaa dan H. Setiawan, "Perancangan Mesin Pengolah Air Bersih Bergerak Dengan Menggunakan Sistem Modular Untuk Penaggulangan Keadaan Darurat Air," IRWNS, pp. 278-285, 2013. 